\title{
IMPLIKASI YURIDIS JUAL BELI TANAH ADAT MELALUI PERJANJIAN DIBAWAH TANGAN DALAM PERSPEKTIF UNDANG-UNDANG POKOK AGRARIA
}

\author{
I Gusti Ayu Widiadnyani, Ratna Artha Windari, Ketut Suditmaka \\ Jurusan Ilmu Hukum \\ Universitas Pendidikan Ganesha \\ Singaraja, Indonesia
}

e-mail: \{ayu.widiadnyani, ratnawindari, sudiatmaka\}@undiksha.ac.id

\begin{abstract}
Abstrak
Penelitian ini bertujuan untuk mengetahui implikasi yuridis perjanjian jual beli tanah adat melalui kesepakatan dibawah tangan dalam perspektif Undang-Undang Nomor 5 Tahun 1960 dan untuk mengetahui kekuatan pembuktian perjanjian jual beli tanah dibawah tangan apabila terjadi sengketa. Metode penelitian yang digunakan dalam tulisan ini adalah metode penelitian hukum normatif. Di dalam penelitian ini pendekatan yang digunakan adalah pendekatan perundang-undangan (Statute Approach), dan pendekatan konseptual (Conseptual Approach). Sumber bahan hukum yang digunakan dalam penelitian ini adalah bahan hukum primer, bahan hukum skunder dan bahan hukum tersier. Analisis bahan hukum dilakukan secara deskriptif selanjutnya data yang telah diperoleh disusun secara sistematis, kemudian ditarik kesimpulan. Hasil penelitian menunjukkan bahwa implikasi yuridis perjanjian jual beli tanah adat melalui kesepakatan dibawah tangan menurut Undang-Undang Nomor 5 Tahun 1960 adalah jual beli tanah yang dilakukan dibawah tangan (tanpa akta Pejabat Pembuat Akta Tanah) tetaplah sah, karena sudah terpenuhinya syarat sahnya jual beli menurut pasal 5 Undang-Undang Nomor 5 Tahun 1960 yaitu syarat materiil yang bersifat tunai, terang dan riil. Selain itu juga jual beli tersebut sudah memenuhi syarat jual beli menurut Pasal 1320 Kitab Undang-Undang Hukum Perdata syarat sahnya perjanjian. Kekuatan pembuktian perjanjian jual beli tanah dibawah tangan apabila terjadi sengketa yaitu berdasarkan akta dibawah tangan yang telah memperoleh legalisasi dari Notaris membantu Hakim dalam hal pembuktian, yang tertuang dalam Pasal 15 ayat (2) Undang-Undang Nomor 2 Tahun 2014. Untuk memiliki kekuatan pembuktian yang paripurna pembeli dapat memperkuat bukti kepemilikan setelah terjadi jual beli dengan pensertifikatan berdasarkan Pasal 19 ayat (2) huruf c UUPA dan Pasal 32 ayat (1) PP Nomor 24 Tahun 1997 sebagai tanda bukti hak yang berlaku dan sebagai alat pembuktian yang kuat.
\end{abstract}

Kata kunci: implikasi yuridis, jual beli dibawah tangan, tanah adat, Undang-Undang Nomor 5 Tahun 1960

\footnotetext{
Abstract

The study aimed at finding out the juridical implication of sale and purchase agreement customary land through underhand agreement in law number 5 of 1960 perspective, and to find out the value of evident on underhand agreement if conflict happens. The study implemented a normative legal research method using Statute Approach and Conceptual Approach. There were three sources of legal material, such as primary, secondary, and tertiary legal materials implemented in this study. The descriptive technique was used to analyze legal materials. Then, the obtained data of legal materials were arranged systematically and finally conclusion was drawn. The result of the study indicated that based on law number 5 of 1960, the juridical implication of sale and purchase agreement customary land through underhand agreement remains legitimate due to the fulfillment of material requirements, which are cash, coherent, and real, of sale and purchase agreement activity based on Article 5 Law number 5 of 1960. In addition, the sale and purchase agreement land without the Deed of the Land Deed Official is legitimate as it fulfills the legal requirement of agreement based on Article 1320 of Civil Law Code. In terms of conflict, based on Article 15 Paragraph (2) of Law Number 2 of 2014, the value of evident on underhand agreement in sale and purchase agreement land is a legalized underhand deed in case of proof which is received from Notary Assistant of Judge. According to Article 19 Paragraph (2) Alphabet
} 
C UUPA and Article 32 Paragraph (1) PP Number 24 of 1997, customer possesses plenary authentication power if the sale and purchase agreement proofs and deed are strengthened. This is a valid proof of rights and powerful evidentiary tool.

Keywords: juridical implication, underhand sale and purchase agreement, customary land, Law Number 5 of 1960

\section{PENDAHULUAN}

Di dalam kehidupan sehari-hari tanah memiliki hubungan yang sangat erat dengan kehidupan manusia. Jumlah luas tanah yang dapat dikuasai oleh manusia masih terbatas, sedangkan jumlah manusia yang membutuhkan tanah senantiasa bertambah. Selain itu banyak terjadi transaksi dalam masyarakat sehubungan dengan masalah tanah, seperti : perjanjian jual beli, sewa menyewa, tukar menukar, gadai dan sebagainya. Dari sekian banyak transaksi yang terjadi, maka yang paling banyak dijumpai dalam masyarakat mengenai transaksi jual beli. Tidak seimbangnya antara persediaan tanah dengan kebutuhan akan tanah itu telah menimbulkan berbagai persoalan.

Menurut Hukum Adat maka jual beli tanah merupakan suatu perbuatan pemindahan hak atas tanah yang bersifat terang dan tunai. Dimana perpindahan hak atas tanah tersebut serentak terjadi begitu pembayaran harga diserahkan kepada pembeli, hal semacam ini dikenal dengan asas konkrit/kontan atau riil.

Namun tidak dapat dipungkiri, dalam kehidupan masyarakat seharihari masih banyak jual beli dilakukan dibawah tangan dalam arti bahwa jual beli tersebut cukup dilakukan dengan kesepakatan kedua belah pihak dan disaksikan oleh para saksi. Apabila dianggap kurang meyakinkan maka dibuatkan kwitansi, ataupun jika ingin perjanjian jual beli agar lebih jelas isinya maka dibuatkanlah pernyataan yang ditulis di atas kertas segel yang ditandatangani oleh kedua belah pihak serta disaksikan oleh orang-orang tertua di desa disahkan oleh Kepala
Desa setempat (Sumaryono, Tesis, 2009:14).

Sedangkan dalam Pasal 37 ayat

1 Peraturan Pemerintah Nomor 24

Tahun 1997 mewajibkan setiap perjanjian yang berkenaan dengan pemindahan hak atas tanah harus dibuat di hadapan Pejabat PPAT yang telah ditunjuk. Di lain pihak, Pemerintah juga mengeluarkan suatu peraturan yang berbunyi sebagaimana lebih lanjut diuraikan dalam Pasal 37 ayat (2) Peraturan Pemerintah Nomor 24 Tahun 1997 tentang pendaftaran tanah yang berbunyi :

Bahwa dalam keadaan tertentu sebagaimana yang ditentukan oleh Menteri, Kepala Kantor Pertanahan dapat mendaftar peralihan hak milik atas tanah yang dilakukan diantara Warga Negara Indonesia yang dibuktikan dengan akta yang tidak dibuat oleh Pejabat Pembuat Akta Tanah, tetapi menurut Kantor Pertanahan tersebut kadar kebenarannya dianggap cukup untuk mendaftar peralihan hak yang bersangkutan.

Dalam hal ini menimbulkan suatu pertanyaan di kalangan masyarakat dimana dalam peralihan jual beli hak atas tanah adat melalui kesepakatan dibawah tangan, masih menimbulkan kerancuan dalam menentukan kepastian hukum.

Berdasarkan uraian diatas, maka permasalahan yang dikemukakan dalam penelitian ini adalah sebagai berikut: (1) Bagaimanakah implikasi yuridis perjanjian jual beli tanah adat melalui kesepakatan dibawah tangan dalam perspektif Undang-Undang Nomor 5 Tahun 1960 dan (2) Bagaimanakah kekuatan pembuktian perjanjian jual beli tanah dibawah tangan apabila terjadi sengketa. 


\section{METODE}

Penelitian ini menggunakan jenis penelitian yuridis normatif dengan rasionalitas bahwa penelitian ini akan mengkaji mengenai implikasi yuridis jual beli tanah adat melalui perjanjian dibawah tangan dan kekuatan pembuktian perjanjian jual beli tanah dibawah tangan apabila terjadi sengketa.

$\mathrm{Di}$ dalam penelitian ini pendekatan yang digunakan adalah pendekatan perundang-undangan (Statute Approach), dan pendekatan konseptual (Conseptual Approach). Sedangkan sumber bahan hukum yang digunakan dalam penelitian ini adalah bahan hukum primer, bahan hukum skunder dan bahan hukum tersier.

Adapun teknis analisis bahan hukum dilakukan secara deskriptif, yaitu analisis yang dilakukan dengan memaparkan permasalahan implikasi yuridis jual beli tanah adat melalui perjanjian dibawah tangan dalam perspektif Undang-Undang Nomor 5 Tahun 1960 maupun kekuatan pembuktian perjanjian jual beli tanah dibawah tangan apabila terjadi sengketa serta merangkai data yang telah diperoleh dan disusun secara sistematis, kemudian ditarik kesimpulan.

\section{HASIL DAN PEMBAHASAN}

Implikasi Yuridis Perjanjian Jual Beli Tanah Adat Melalui Kesepakatan dibawah Tangan dalam Perspektif Undang-Undang Nomor 5 Tahun 1960

\section{Perjanjian Jual Beli Tanah Adat Melalui Kesepakatan dibawah Tangan Sebelum Berlakunya Undang-Undang Pokok Agraria (UUPA)}

Sebelum berlakunya UndangUndang Pokok Agraria (UUPA), Undang-Undang Nomor 5 Tahun 1960, pada tanggal 24 September 1960, jual beli tanah di Indonesia mempergunakan dua sistem hukum, yaitu sistem Hukum Barat bagi golongan Eropa dan sistem Hukum Adat bagi golongan bumi putera atau pribumi.

1. Menurut Hukum Barat

Belanda pada saat datang dan menjajah di Indonesia pada masa lalu juga membawa perangkat Hukum Belanda untuk mengatur masyarakat di Indonesia. Pada tanggal 1 Mei 1848 mulai diberlakukan suatu ketentuan Hukum Barat yang tertulis yaitu Burgelijk Wetboek (BW), yang sampai sekarang masih dikenal sebagai Kitab UndangUndang Hukum Perdata.

Sedangkan menurut Pasal 1320 Kitab Undang-Undang Hukum Perdata untuk sahnya suatu perjanjian harus memenuhi 4 syarat, yaitu: (Ariyani, 2013:6)

a. Ada persetujuan kehendak antara pihak-pihak yang membuat perjanjian (sepakat);

b. Ada kecakapan pihak-pihak untuk membuat perjanjian;

c. Ada sesuatu hal tertentu;

d. Ada sesuatu sebab yang halal.

2. Menurut Hukum Adat

Pengertian jual beli menurut Hukum Adat adalah perbuatan hukum pemindahan hak yang bersifat tunai (Harsono, 2003:333). Jual beli tanah dalam hukum adat, adalah perbuatan hukum pemindahan hak atas tanah dengan pembayaran harganya pada saat yang bersamaan secara tunai dilakukan. Maka dengan penyerahan tanahnya kepada pembeli dan pembayaran harganya kepada penjual pada saat jual beli dilakukan, perbuatan jual beli itu selesai dalam arti pembeli telah menjadi pemegang hak yang baru.

Dalam masyarakat Hukum Adat jual beli tanah dilaksanakan secara terang dan tunai (Perangin, 1989:16):

a. Kontan atau tunai

Harga tanah yang dibayar itu bisa seluruhnya tetapi bisa juga sebagaian. Tetapi biarpun dibayar sebagian, menurut hukum dianggap telah dibayar penuh. Pembayaran harga dan 
penyerahan haknya dilakukan pada saat yang bersamaan. Jual beli menurut hukum adat telah selesai, sisa harga yang belum dibayar dianggap sebagai suatu utang pembeli kepada bekas pemilik tanah.

\section{b. Terang}

Jual beli tanah dilakukan dihadapan kepala desa atau kepala adat. Hal ini dilakukan agar pembeli mendapatkan pengakuan dari masyarakat yang bersangkutan sebagai pemilik tanah yang baru dan mendapatkan perlindungan hukum jika di kemudian hari ada gugatan terhadapnya dari pihak yang menganggap jual beli tanah tersebut tidak sah.

\section{Perjanjian Jual Beli Tanah Adat (Sesudah Berlakunya Undang- Undang Pokok Agraria (UUPA) \\ Berlakunya Undang-Undang} Nomor 5 Tahun 1960 tentang Peraturan Dasar Pokok-Pokok Agraria (selanjutnya disebut UUPA) yang mulai berlaku pada tanggal 24 September 1960 telah terjadi perubahan fundamental pada hukum agraria di Indonesia terutama pada hukum pertanahan. Perubahan ini bersifat mendasar baik pada struktur perangkat hukumnya maupun pada konsepsi dan isinya.

Dengan dibentuknya UUPA sebagai hukum tanah nasional, maka dualisme hukum tanah sudah tidak ada lagi dan telah memberikan unifikasi dalam hukum pertanahan. Berbeda dengan jual beli yang terjadi menurut UUPA yang memerlukan akta otentik (akta jual beli) yang dibuat oleh dan dihadapan Pejabat Pembuat Akta Tanah (PPAT) yang tercantum dalam beberapa perundang-undangan, yaitu berdasarkan Pasal 1 Angka 4 UndangUndang Nomor 4 Tahun 1996 tentang Hak Tanggungan Atas Tanah Beserta Benda-Benda Yang Berkaitan Dengan Tanah (UUHT), menyebutkan bahwa "Pejabat Pembuat Akta Tanah, selanjutnya disebut PPAT adalah
Pejabat Umum yang diberi wewenang untuk membuat akta Pemindahan Hak Atas Tanah, Akta Pembebanan Hak Tanggungan, dan Akta Pemberi Kuasa membebankan Hak Tanggungan menurut peraturan perundangundangan yang berlaku.

Sejak berlakunya UndangUndang Nomor 5 Tahun 1960 tentang Peraturan Dasar Pokok-Pokok Agraria dengan peraturan pelaksananya yakni Peraturan Pemerintah Nomor 10 Tahun 1961 yang telah diganti dengan Peraturan Pemerintah Nomor 24 Tahun 1997, maka jual beli tanah hanya boleh dilakukan dengan akta Pejabat Pembuat Akta Tanah. Pasal 37 Ayat (1) Peraturan Pemerintah Nomor 24 Tahun 1997 menyebutkan bahwa peralihan hak atas tanah melalui jual beli hanya dapat didaftarkan jika dibuktikan dengan akta yang dibuat Pejabat Pembuat Akta Tanah yang berwenang menurut ketentuan perundang- undangan. Sehingga perjanjian jual beli tanah hanya boleh dilakukan dengan akta Pejabat Pembuat Akta Tanah sebagai buktinya untuk mendaftarkan peralihan hak atas tanahnya di Kantor Pertanahan.

Dalam ketentuan Pasal 19 UUPA jo Pasal 37 ayat (1) PP Nomor 24 Tahun 1997, maka setiap peralihan hak atas tanah harus dibuat akta, sedangkan aktanya harus dibuat oleh pejabat yang diberi wewenang untuk membuat aktaakta tanah tertentu yang ditunjuk oleh Menteri Agraria/Kantor Badan Pertanahan Nasional (KBPN).

\section{Akibat Hukum Perjanjian Jual Beli Tanah dibawah Tangan}

Peraturan Pemerintah Nomor 24 Tahun 1997 Tentang Pendaftaran Tanah Pasal 37 yang mewajibkan peralihan hak karena jual beli hanya bisa di daftarkan apabila dibuat oleh PPAT tetapi tidak adanya sanksi kepada masyarakat apabila peralihan hak atas tanah dilakukan secara dibawah tangan sebagaimana halnya sanksi yang diberikan kepada PPAT apabila dalam jangka 7 hari tidak 
mendaftarkan akta yang dibuatnya ke kantor Pertanahan untuk didaftar. Kewajiban yang dibebankan kepada PPAT ini ditujukan untuk memberikan kepastian hukum bagi kliennya dan untuk dapat terselenggaranya tertib administrasi pertanahan sebagaimana merupakan salah satu daripada tujuan pendaftaran tanah. Pendaftaran akta oleh PPAT ke Kantor Pertanahan adalah untuk memenuhi asas publisitas sehingga masyarakat umum dapat mengetahui karena sifat administrasi Kantor Pertanahan bersifat terbuka. Berbeda dengan administrasi PPAT yang sifatnya tertutup, yang hanya dapat diketahui oleh para pihak dan ahli warisnya saja.

Kewenangan lembaga penegak hukum dijamin oleh undang-undang. Sehingga dalam melaksanakan tugas dan tanggung jawabnya terlepas dari pengaruh kekuasaan pemerintah dan pengaruh-pengaruh lain. Terdapat adagium yang menyatakan (meskipun dunia ini runtuh hukum harus di tegakkan). Hukum tidak dapat berjalan atau tegak bila tidak ada aparat penegak hukum yang kredibilitas, kompeten dan independen. Seberapa bagusnya suatu peraturan perundang- undangan bila tidak didukung dengan aparat penegak hukum yang baik maka keadilan hanya angan-angan. Lemahnya mentalitas aparat penegak hukum mengakibatkan penegakkan hukum tidak berjalan sebagaimana mestinya. Banyak faktor yang mempengaruhi lemahnya mentalitas aparat penegak hukum diantaranya lemahnya pemahaman agama, ekonomi, proses rekruitmen yang tidak transparan dan lain sebagainya. Maka faktor penegak hukum memainkan peran penting dalam menjalankan fungsi hukum.

Apabila peraturan perundangundangan sudah baik, tetapi kualitas penegak hukumnya masih rendah maka akan terdapat masalah, demikian juga apabila peraturan perundangundangannya buruk, sedangkan kualitas penegak hukumnya baik tetap akan muncul kemungkinan masalah juga. Kantor Pertanahan meskipun telah melakukan pembinaan kepada PPAT agar mematuhi ketentuan- ketentuan yang telah diatur dalam Peraturan Pemerintah Nomor 24 tahun 1997 Tentang Pendaftran Tanah tetapi pihak kantor Pertanahan tidak memberikan sanksi apapun kepada PPAT yang bersangkutan sebagaimana yang diatur dalam Pasal 62 Peraturan Pemerintah Nomor 24 tahun 1997 Tentang Pendaftaran Tanah.

Selain itu adanya suasana pemikiran sosial dan kekuatan sosial yang menentukan bagaimana hukum digunakan, dihindari, atau disalahgunakan. Dalam budaya hukum erat kaitannya dengan kesadaran hukum masyarakat. Masyarakat dan budaya merupakan fenomena yang tidak terpisahkan. Antara unsur-unsur budaya terjalin satu sama lain dan saling berpengaruh, perubahan pada salah satu unsur saja akan menyebabkan perubahan pada unsur- unsur lainnya. Maka sama sekali tidak dapat di lepaskan dari keterkaitannya dengan proses-proses sosial yang berlangsung dalam masyarakat sebagai hasil dari kontruksi sosial (Dimyati, 2004:107). Selama ini masyarakat tidak mengetahui mengenai peralihan hak atas tanah tidak bisa didaftarkan ke Kantor Pertanahan apabila akta tidak dibuat oleh PPAT sehingga masyarakat sering melakukan transaksi jual beli hak atas tanah dilakukan secara dibawah tangan. Hal ini dikarenakan kurangnya sosialisasi dari pihak kantor Pertanahan kepada masyarakat.

Bahwa akibat hukum jual beli tanah yang dilakukan dibawah tangan (tanpa akta Pejabat Pembuat Akta Tanah) tetaplah sah, karena sudah terpenuhinya syarat sahnya jual beli menurut Pasal 5 Undang- Undang Nomor 5 Tahun 1960 yaitu syarat materiil yang bersifat tunai, terang dan riil. Selain itu juga jual beli tersebut sudah memenuhi syarat jual beli menurut Pasal 1320 Kitab Undang- 
Undang Hukum Perdata yang merupakan syarat sahnya perjanjian. Tetapi untuk memperoleh pemindahan hak atas tanah dan balik nama harus memiliki akta yang dibuat oleh PPAT karena pemindahan hak atas tanah melalui jual beli tanah harus dibuktikan dengan akta yang dibuat oleh PPAT.

Upaya penyelesaian yang dapat dilakukan oleh pihak pembeli agar jual beli tanah yang dilakukan tanpa akta PPAT dapat mempunyai kekuatan hukum yang pasti dengan menghadap ke Kepala desa, pihak pembeli dan pihak penjual menghadap langsung Kepala desa, karena Kepala Desa dianggap orang yang mengetahui hukum. Kemudian oleh penjual dibuat suatu akta bermaterai yang menyatakan bahwa benar ia telah menyerahkan tanah miliknya untuk selama-lamanya kepada pembeli. Akta tersebut ditandatangani oleh pembeli dan Kepala Desa dan disaksikan oleh dua orang saksi yang cakap menurut hukum.

\section{Kekuatan Pembuktian Perjanjian Jual Beli Tanah Dibawah Tangan Apabila Terjadi Sengketa}

Suatu bidang tanah tidak atau belum mempunyai sertifikat, maka dapat dibuktikan dengan bukti-bukti lainnya sebagaimana ditentukan dalam ketentuan perundang-undangan. Pembuktian dalam konteks keperdataan dan dalam jual beli tanah mengacu kepada kekuatan pembuktian sebagaimana yang tercantum di dalam Pasal 164 HIR/284 RBg, dan Pasal 1866 Kitab Undang-Undang Hukum Perdata yang terdiri dari bukti tulisan, bukti persangkaan-persangkaan, bukti pengakuan, bukti sumpah dan bukti dengan akta serta Pasal 23 dan Pasal 24 PP Nomor 24 Tahun 1997 yang mengatur mengenai pembuktian hak atas tanah untuk keperluan pendaftaran hak atas tanah.

Dalam hukum pembuktian dikenal tiga jenis surat, yaitu akta otentik, akta dibawah tangan dan surat bukan akta. Akta otentik adalah akta yang dibuat oleh atau dihadapan pegawai umum yang berwenang dalam bentuk menurut undang-undang dimana akta dibuat (Pasal 1868 BW). Akta otentik mempunyai kekuatan pembuktian sempurna, yaitu cukup berdiri sendiri, tidak perlu ditambah alat bukti lain, dan isinya dianggap benar selama tidak dibuktikan sebaliknya (Sugeng dan Sujayadi, 2012:68). Akta dibawah tangan cara pembuatan atau terjadinya tidak dilakukan oleh dan atau dihadapan pejabat pegawai umum, tetapi cukup oleh pihak yang berkepentingan saja (Pasal 1874 Kitab Undang-Undang Hukum Perdata dan Pasal $286 \mathrm{RBg}$ ).

Akta dibawah tangan mempunyai kekuatan pembuktian sepanjang isi dan tanda tangan yang tercantum di dalamnya diakui oleh para pihak. Jika salah satu pihak mengingkarinya, maka nilai pembuktian tersebut diserahkan kepada hakim. Dengan telah dilegalisasi akta dibawah tangan maka bagi Hakim telah diperoleh kepastian mengenai tanggal dan identitas para pihak yang mengadakan perjanjian tersebut serta tanda tangan yang dibubuhkan dibawah surat itu benar berasal dan dibubuhkan oleh orang yang namanya tercantum dalam surat itu dan orang yang membubuhkan tanda tangannya dibawah surat itu tidak lagi dapat mengatakan bahwa para pihak atau salah satu pihak tidak mengetahui apa isi surat itu, karena isinya telah dibacakan dan dijelaskan terlebih dahulu sebelum para pihak membubuhkan tanda tangannya di hadapan pejabat umum tersebut.

Berdasarkan hal tersebut, maka akta dibawah tangan yang telah memperoleh legalisasi dari Notaris membantu Hakim dalam hal pembuktian, karena dengan diakuinya tanda tangan tersebut, maka isi aktapun dianggap sebagai kesepakatan para pihak karena akta dibawah tangan kebenarannya 
terletak pada tanda tangan para pihak yang terkait baik penjual, pembeli, dan pejabat pembuat akta jual beli tanah/PPAT yang tertuang dalam Pasal 15 ayat (2) Undang-Undang Nomor 2 Tahun 2014, dengan ditandatanganinya akta jual beli tersebut maka akta tersebut menjadi bukti yang sempurna (Neriana, JOM Fakultas Hukum, Vol. 2 No. 2 Oktober 2015:8-9).

Namun apabila terjadi saling klaim suatu objek tanah dimana salah satu pihak memiliki akta dibawah tangan yang telah memperoleh legalisasi dari Notaris sedangkan pihak lawan mengeluarkan sertifikat maka akta dibawah tangan tersebut pembuktiannya masih lemah, dimana akta dibawah tangan yang telah memperoleh legalisasi dari Notaris merupakan alat atau syarat untuk membuat sertifikat sehingga untuk memiliki kekuatan pembuktian yang paripurna maka hak atas tanah yang terjadinya berdasarkan penetapan pemberian hak dari pejabat yang berwenang hanya dapat dibuktikan dengan sertifikat. Berdasarkan Pasal 1 angka 20 PP Nomor 24 Tahun 1997, sertifikat adalah surat tanda bukti hak sebagaimana dimaksud dalam Pasal 19 ayat (2) huruf c UUPA untuk hak atas tanah, hak pengelolaan, tanah wakaf, hak milik atas satuan rumah susun dan hak tanggungan yang masing-masing sudah dibukukan dalam buku tanah yang bersangkutan.

Menurut Pasal 19 ayat (2) huruf c UUPA dan Pasal 32 ayat (1) PP Nomor 24 Tahun 1997 bahwa sertifikat merupakan surat bukti hak atas tanah berlaku sebagai alat pembuktian yang kuat. Sertifikat sebagai alat bukti hak atas tanah diterbitkan oleh Kantor Pertanahan Kabupaten/Kota melalui suatu proses pendaftaran tanah, apabila suatu bidang tanah belum dilaksanakan pendaftaran tanahnya maka atas bidang tanah tersebut tidak mempunyai sertifikat. Sertifikat diterbitkan oleh BPN (Badan Pertanahan Nasional) yang didalamnya memuat data fisik dan data yuridis suatu bidang tanah tertentu.

Data fisik berkenaan dengan letak, batas dan luas bidang tanah. Sedangkan data yuridis berkenaan dengan subyek hak, alas hak dan pembebanan hak atas tanah. Data tersebut diperoleh dari pemohon sertifikat dan pemeriksaan oleh BPN melalui proses pendaftaran tanah (Arba, 2017:148). Karena itu dalam kaitannya dengan alat-alat bukti dalam proses peradilan perdata sebagaimana dimaksud dalam Pasal 164 HIR/284 $\mathrm{RBg}$ dan Pasal 1866 Kitab UndangUndang Hukum Perdata maka sertifikat berstatus sebagai bukti surat yang berkualifikasi sebagai akta otentik (Ismail, Kanun Jurnal IImu Hukum, No. 53, April 2011:27).

Salah satu fungsi akta adalah sebagai alat pembuktian. Sebagai alat pembuktian akta dibedakan dalam tiga macam kekuatan pembuktian, yaitu: kekuatan pembuktian lahir, kekuatan pembuktian formal dan kekuatan pembuktian material (Samudra , 2004:47-49). Kekuatan bukti lahir merupakan kekuatan bukti yang didasarkan atas keadaan lahir bahwa suatu surat yang kelihatannya seperti akta dianggap/diterima sebagai suatu akta dan harus diperlakukan sebagai akta sepanjang tidak terbukti kebalikannya. Sedangkan kekuatan bukti formal merupakan kekuatan bukti yang didasarkan atas benar atau tidaknya pernyataan dalam akta bahwa penandatangan akta menerangkan apa yang tercantum dalam akta.

Sementara itu kekuatan pembuktian material merupakan kekuatan pembuktian yang didasarkan atas benar atau tidaknya isi dari pernyataan bahwa penandatangan menyatakan bahwa peristiwa hukum yang dinyatakan dalam akta itu benarbenar telah terjadi. Sertifikat yang mempunyai kedudukan sebagai akta otentik mempunyai kekuatan pembuktian lahir, formil dan materil dan berdasarkan Pasal 165 HIR bahwa akta otentik mempunyai kekuatan yang 
sempurna. Artinya apa yang tercantum didalamnya harus diterima sebagai suatu yang benar selama tidak ada pihak yang dapat membuktikan sebaliknya.

Bahwa pembeli dapat memperkuat bukti kepemilikan setelah terjadi jual beli dengan pensertifikatan. Berdasarkan Pasal 19 ayat (2) huruf $\mathrm{c}$ UUPA yang menyebutkan bahwa kegiatan pendaftaran tanah meliputi; "Pemberian surat-surat tanda bukti hak, yang berlaku sebagai alat pembuktian yang kuat". Demikian juga halnya Pasal 32 ayat (1) PP Nomor 24 Tahun 1997 yang menyebutkan; "sertifikat merupakan surat tanda bukti hak yang berlaku sebagai alat pembuktian yang kuat mengenai data fisik dan data yuridis yang termuat di dalamnya, sepanjang data fisik dan data yuridis tersebut sesuai dengan data yang ada dalam surat ukur dan buku tanah hak yang bersangkutan".

Sebagai konsekuensi dari terciptanya kepastian hukum mengenai subyek dan obyek maka dengan diterbitkannya sertifikat tersebut dapat menimbulkan beberapa fungsi bagi pemiliknya yaitu : (S.R, Jurnal IImu Pemerintahan, Vol 3, No. 1, 2015:271272)

a. Nilai ekonomisnya (harga jual) lebih tinggi. Dalam jual beli pada umumnya pembeli (konsumen) memilik pandangan, lebih baik kalah dalam membeli tetapi menang dalam pemakaian daripada menang membeli tetapi kalah dalam memakai. Bertolak dari pandangan seperti itulah sehingga tanah yang telah bersertifikat memiliki harga yang jauh lebih tinggi dibandingkan dengan tanah yang belum bersertifikat. Karena tanah yang telah bersertifikat telah memiliki jaminan kepastian.

b. Tanah lebih mudah dijadikan sebagai jaminan utang.

c. Tidak setiap orang memiliki kemampuan ekonomi yang cukup, dimana sering ditemukan orang dalam mempertahankan hidupnya harus meminjam uang dari pihak/orang lain. Demikian juga halnya dengan para pelaku usaha, bahwa tidak setiap pelaku usaha memiliki modal yang cukup untuk tetap bertahan atau mengembangkan usahanya, terkadang harus membutuhkan dana yang cukup besar, sementara dana dimaksud tidak dimilikinya. Suatu alternatif yang dapat ditempuh adalah dengan cara meminjam dana dari orang/pihak lain.

\section{SIMPULAN DAN SARAN}

Berdasarkan pembahasan dari keseluruhan hasil penelitian maka dapat disimpulkan sebagai berikut:

1. Implikasi yuridis perjanjian jual beli tanah adat melalui kesepakatan dibawah tangan menurut UndangUndang Nomor 5 Tahun 1960 adalah jual beli tanah yang dilakukan dibawah tangan (tanpa akta Pejabat Pembuat Akta Tanah) tetaplah sah, karena sudah terpenuhinya syarat sahnya jual beli menurut Pasal 5 Undang- Undang Nomor 5 Tahun 1960 yaitu syarat materiil yang bersifat tunai, terang dan riil. Selain itu juga jual beli tersebut sudah memenuhi syarat jual beli menurut Pasal 1320 Kitab Undang-Undang Hukum Perdata yang merupakan syarat sahnya perjanjian. Tetapi untuk memperoleh pemindahan hak atas tanah dan balik nama harus memiliki akta yang dibuat oleh PPAT karena pemindahan hak atas tanah melalui jual beli tanah harus dibuktikan dengan akta yang dibuat oleh PPAT.

2. Kekuatan pembuktian perjanjian jual beli tanah dibawah tangan apabila terjadi sengketa yaitu berdasarkan akta dibawah tangan yang telah memperoleh legalisasi dari Notaris membantu Hakim dalam hal pembuktian, karena dengan diakuinya tanda tangan tersebut, maka isi aktapun 
dianggap sebagai kesepakatan para pihak karena akta dibawah tangan kebenarannya terletak pada tanda tangan para pihak yang terkait baik penjual, pembeli, dan pejabat pembuat akta jual beli tanah/PPAT yang tertuang dalam dalam Pasal 15 ayat (2) UndangUndang Nomor 2 Tahun 2014, dengan ditandatanganinya akta jual beli tersebut maka akta tersebut menjadi bukti yang sempurna. Untuk memiliki kekuatan pembuktian yang paripurna pembeli dapat memperkuat bukti kepemilikan setelah terjadi jual beli dengan pensertifikatan berdasarkan Pasal

19 ayat (2) huruf $c$ UUPA dan Pasal 32 ayat (1) PP Nomor 24 Tahun 1997 sebagai tanda bukti hak yang berlaku dan sebagai alat pembuktian yang kuat.

Adapun dari hasil penelitian, penulis dapat menyampaikan saran-saran sebagai berikut:

1. Kepada masyarakat dengan diterbitkannya PP No. 24 tahun 1997, pemerintah telah mengarahkan para pihak untuk melakukan jual beli hanya melalui PPAT. Namun pada prakteknya hingga saat ini, masih terjadi perjanjian jual beli tanah dibawah tangan. Pembeli beritikad baik dapat dipahami sebagai pembeli yang telah memenuhi prosedur (pembelian tanah melalui PPAT) maupun bersikap hati-hati dengan melaksanakan sesuai prosedur dan terlindungi haknya apabila terjadi sengketa sehingga pihak yang dirugikan dapat mengajukan gugatan ganti rugi kepada penjual yang ternyata tidak berhak.

2. Kepada Kantor Pertanahan hendaknya sering mengadakan penyuluhan hukum mengenai peraturan yang berlaku bagi kepentingan masyarakat banyak maupun masyarakat sebagai pihak yang akan melakukan pengalihan atau pihak yang akan menerima hak hendaknya mencari informasi terlebih dahulu pada Kantor Pertanahan setempat sebelum melakukan pendaftaran peralihan hak sehingga proses pendaftaran dapat berjalan dengan lancar serta dapat mewujudkan kepastian dan perlindungan hukum.

\section{DAFTAR PUSTAKA}

Akbar, Putra. 2008. Kitab UndangUndang Hukum Perdata. Jakarta: Wipress.

Arba, H. M. 2017. Hukum Agraria Indonesia. Cetakan Ke- 3 Jakarta: Sinar Grafika.

Dimyati, Khudzaifah. 2004. Teorisasi Hukum. Surakarta: Muhammadiyah University Press.

Indonesia, Undang-Undang No. 5 Tahun 1960 tentang Peraturan Dasar PokokPokok Agraria, Lembaran Negara. No. 104 Tahun 1960.

Ismail, Ilyas. 2011. "Sertifikat sebagai Alat Bukti Hak Atas Tanah dalam Proses Peradilan". Volume 14, Nomor 53.

Kementerian Negara Agraria/Badan Pertanahan Nasional, Peraturan Menteri Negara Agraria/Kepala BPN No. 3 Tahun 1997 tentang Ketentuan Pelaksanaan Peraturan Pemerintah No. 24 Tahun $1997 \quad$ Tentang Pendaftaran Tanah.

Neriyana, 2015. "Kekuatan Pembuktian Akta Dibawah Tangan Perjanjian Dihubungkan Jual $\begin{array}{r}\text { Beli } \\ \text { Dengan }\end{array}$ Kewenangan Notaris Dalam Pasal 15 Ayat (2) UndangUndang Nomor 2 Tahun 2014 Tentang Perubahan Atas Undang-Undang Nomor 30 Tahun 2004 Tentang Jabatan Notaris". JOM Fakultas Hukum. Volume 2 Nomor 2 Oktober.

Peraturan Pemerintah Nomor 24 Tahun 2016 tentang Peraturan Jabatan 
e-Journal KomunitasYustitia Universitas Pendidikan Ganesha Jurusan Ilmu Hukum (Volume 1 No. 1 Tahun 2018)

Pejabat Pembuat Akta Tanah

(PPAT).

S R, Septianingsih. 2015. "Studi

Tentang Pelayanan Penerbitan

Sertifikat Tanah". Fakultas IImu

Sosial dan IImu Politik, Volume.

3, Nomor 1.

Samudra, Teguh. 2004. Hukum

Pembuktian Dalam Acara

Perdata. Bandung: Alumni.

Sugeng, Bambang dan Sujayadi. 2012. Pengantar Hukum Acara Perdata dan Contoh Dokumen Litigasi. Jakarta: Kencana Prenada Media Group.

Sumaryono. 2009. "Jual Beli Tanah Yang Dilakukan Tanpa Akta Jual Beli Pejabat Pembuat Akta Tanah (PPAT) (Analisis Kasus Nomor: 220/Pdt.G/2006/

PN.Bks)". Tesis. Program

Pascasarjana, Universitas Diponegoro Semarang.

Undang-Undang Nomor 2 Tahun 2014

Tentang Jabatan Notaris. 